\title{
Third Space, Hybridity, and Colonial Mimicry in Fugard's Blood Knot
}

\author{
Parvin Ghasemi
}

Shiraz University, Iran

Samira Sasani

Shiraz University, Iran

Fatereh Nemati

Shiraz University, Iran

\section{Introduction}

Harold Athol Lanigan Fugard was born in the small Karoo town of Middleburg, Eastern Cape, South Africa, on June 11, 1932 to English and Afrikaner parents. With his mix heritage from an English father and an Afrikaner mother, Fugard claims his "'English tongue is speaking for an Afrikaner psyche"'(qtd. in Foley 134). The traces of real life and real situation can be seen in the works of this prominent anti-apartheid Afrikaner writer. Since the negative implication of colonialism and racism can be explored, it provided an opportunity to apply postcolonial criticisms.

Apartheid, is an Afrikaans term meaning "apartness" or "separation" and was operated in South Africa from 1948 until early 1990s. Gina Wisker mentioned in her book Key Concepts in Postcolonial Literature that apartheid "separated people in South Africaon the basis of their ethnic origins and skin color"(Wisker 11). Within this policy, the government of Africa separated whites from non-whites, geographically, politically, and economically. It also has been described as the "legalized system of racial discrimination" (Mahlauli, Salani, and Mokotedy 205). Repressing hope, the quality of human life, and the ability to express feelings about life caused many of writers to show their rage in their writings. Among these writers is Athol Fugard who has written many plays which reflect his extreme opposition and hatred toward the apartheid system.

What is known today as a postcolonial theory has a long, vast and complex history that cannot be exhausted in this brief section. But to give a small hint of its 
account, Lazare S.Rukundwa and Andries G. van Aarde, declare: "postcolonial theory is a product of what the West saw as antislavery activists and anticolonialists" (1175). Postcolonial reading is the study of the effects of imperialism and colonialism on culture, society and individuals. Postcolonial studies focus on identity, sex, gender, race, and language of the colonized generation. In other words, it denotes theories and methods which deal with non-material dimensions of colonization.

Among the famous postcolonial critics, Frantz Fanon, Edward Said, and Homi Bhabha are the prominent thinkers whose names have appeared again and again as the critics who have shaped postcolonial theories. Born in 1925, Frantz Fanon published his first controversial book, Black Skin, White Masks in 1952. In it he discussed his psychological analysis of racism and its effects on black people. As he mentions "White men consider themselves superior to black men. There is another fact: Black men want to prove to white men, at all costs, the richness of their thought, the equal value of their intellect" (Fanon 3). Black Skin, White Masks is a psychoanalytical study of racism and colonialism, in order to understand the effects of it on black people or the colonized. Edward Wadie Said as one of the other critics who influenced Bhabha, was born in Palestine in 1935. In 1978, he published his influential book Orientalism, which discusses "Orientalism as a Western style for dominating, restructuring, and having authority over the Orient..." (Said 3). Although Homi Bhabha was influenced by them, he has propagated his new ideas in his book The Location of Culture. His theories on colonialism are different from his predecessors. In other words, his theories decentralize what has been considered as axioms of colonization.

As David Huddart mentioned in his book Homi K. Bhabha, Bhabha's book deals with concepts which "describes ways in which colonized peoples have resisted the power of colonizer..." (1). "We should not see the colonial situation as one of the straightforward oppression of the colonized by the colonizer" (1) Huddart adds. By being on the part of the colonized people, his work also "stresses and extends the agency of colonized peoples" (2). So it can be concluded that in his book Bhabha is working on "cultural difference" and applying them to colonialism which he calls "'colonial discourse analysis'" (3).

In the first chapter of his book which is a collection of his essays written on colonization, Homi Bhabha refers to the concept of "Third Space of enunciation". According to him "all cultural statements and systems are constructed in this contradictory and ambivalent space of enunciation" (55). In other words, as Ilan Kapoor mentions in his article, "Acting in a Tight Spot: Homi Bhabha's Postcolonial Politics" the third space is a "non-dialectical space standing in 
between the binary structures of orientalist representations and imperial power" (566). Ikas and Wagner in the introduction to their book Communicating in the Third space note that "the encounter of two social groups with different cultural traditions and potentials of power as a special kind of negotiation or translation ... takes place in a Third Space of enunciation" (2). Accordingly a new identity will appear. Bill Ashcroft also in his article "Caliban's Voice: Writing in the Third Space" mentions "this space is also a transcultural space, a 'contact zone,' ... that space in which cultural identity develops... the space of postcolonial transformation" (108). So, he believes that both colonizer and the colonized will change in this space and a new identity will appear.

One of the most important concepts to which Bhabha devoted a chapter of his book, is "Colonial Mimicry". In this chapter Bhabha introduces mimicry as an anxiety while the colonized uses it as a resistance strategy. Colonial mimicry or "sly civility" as he calls it later, "is the desire for a reformed, recognizable Other, as a subject of a difference that is almost the same, but not quite" (122). He also mentions that "the discourse of mimicry is constructed around ambivalence; in order to be effective; mimicry must continually produce its slippage, its excess, its difference" (122). The colonizer's anxiety is because of "menace" the mimicry has with itself; "the menace of mimicry is its double vision which in disclosing the ambivalence of colonial discourse also disrupts its authority" (126). Sasani in her article "A Postcolonial Reading of Athol Fugard's "Master Harold" ... and the Boys" states that "[s]ince becoming quite the same means that the colonizer's authentic identity is paradoxically imitable, the colonizer is troubled by the Other, the colonized or the colonizer's double" (458). Huddart mentions that mimicry is "an exaggerated copying of language, culture, manners, and ideas. This exaggeration means that mimicry is repetition with difference, and so it is not evidence of the colonized's servitude" (39). He also states that "colonial discourse wants the colonized to be extremely like the colonizer, but by no means identical" (Huddart 40). According to the pervious established assumptions, the colonizer's power is not imitable. Therefore, Colonial Mimicry denotes a desire and an anxiety, simultaneously.

Hybridity is one of the other concepts, which was emphasized by Bhabha. According to Haj Yazdiha in his article "Conceptualizing Hybridity: Deconstructing Boundaries through the Hybrid", "hybridity arose out of the culturally internalized interactions between 'colonizers' and 'the colonized' and the dichotomous formation of these identities" (31). Bhabha also defines hybridity as "the name of this displacement of value from symbol to sign that causes the dominant discourse to split along the axis of its power to be representative, authoritative" as well as "a problematic of colonial representation and individuation 
that reverses the effects of the colonialist disavowal, so that other 'denied' knowledges enter upon the dominant discourse and estrange the basis of its authority - its rules of recognition" (162). According to David Huddart, "Bhabha believes that hybridity calls into question traditional analyses of colonialism, which tend to merely reverse the terms of colonial knowledge. Again, hybridity is not a consequence of other, apparently 'pure' positions that have been, for one reason or another, thrust together" (23).

Satoshi Mizutani believes that the reason which caused Bhabha to know hybridity as an anxiety for the colonizer was that "[h]ybridity helps the postcolonial critic to upset the discourse of imperialism that would otherwise remain 'unmixed,' uninfluenced by anything other than itself" (30). But why? The colonizers, the "white subject" or the "English gentleman" has always been considered as the "center", "ever present" (31). "He existed, always and anywhere. Like a 'light,' the white subject would reach every corner of the colonized land, its every spot of 'darkness'" Mizutani stipulates (31). But these assumptions would be tenable till they weren't "influenced by the object he colonized" (31). But now this question pops out that "would it ever be possible for the white subject to stay completely aloof from the land he colonizes?" (31) Accordingly, as it was predicted, "this logical contradiction made the colonial discourse of enlightenment equivocal and internally split" (31); the change sets an anxiety among the white subjects. Then, the hybrids created out of these phenomena try to mimic their originals:

The Eurasian subject, as the 'mimic man,' would not be a fixed, stand-alone identity by himself. Rather, the mimic man acted out a performance of repeating, duplicating, or mocking. He would not be an identity since that would make him visible and thus named and categorized by colonial discourse. As Bhabha writes, 'Mimicry repeats rather than re-presents.' The Eurasian subject as mimicry would exist only by relating himself to the original - the white subject. (Mizutani 35)

Thus, the "supposed 'extra-racial' quality of the white subject would become perverted as he was mocked by somebody who was 'white, but not quite'" (35). Therefore, as Mizutani argues in his article, this concept of hybridity challenges the "logic of permanent presence, or of never-changing identity" (36) of the colonial discourse. 


\section{Athol Fugard and South Africa}

Athol Fugard, being a mixed race of an Afrikaner mother and an Anglo-Irish father, has experienced living in both societies which led to the existence of "such a wide variety of characters from different social and economic backgrounds in his work" (Foley 134). As Cohen states in his article "A South African Drama: Athol Fugard's 'The Blood Knot'", what is common in most of Fugard's plays is the difference between his white and his black characters. It is up to them when it is time for the whites to make a decision, but the blacks cannot decide for the simplest issues. Emphasizing the study of this main issue, Fugard shows how Apartheid has affected his character's lives. "The black man has his role chosen for him, and for the whole of his life he is a victim of that choice in whose making he had no part. The white man is his maker and his master" (76). Most of Fugard's plays deal with this South African theme. Using these kinds of themes with lifelike characters, social realism and naturalistic language made his works closer to a true theater of South Africa. Writing in English also helped him to universalize his country's theater and found audiences all around the world to show his hatred of political oppressions. According to Mshengu, by the use of indigenous African language, Fugard has "had entrée into the language and culture of the 'Coloureds' in South Africa" (174) which meant his accession to "the life and culture of the majority" (174) of people living in South Africa.

\section{Setting, Themes, and Characterization in Blood Knot}

Blood Knot written in 1961 has been considered as the "most accomplished, and theatrically most powerful, of the earlier plays" (Crow 154). Blood Knot and two of his other plays Hello and Goodbye and Boesman and Lena were written and set in Port Elizabeth and have been published in a collection entitled Three Port Elizabeth Plays. According to Foley, Fugard started writing Blood Knot when he was in London in 1960, and finished it in 1961 in Port Elizabeth. The play itself is set in Korsten, a local region in Port Elizabeth as it is mentioned in the opening stage direction: "All the action takes place in a one-room shack in the "non-white location' of Korsten, Port Elizabeth" (Fugard 2). Port Elizabeth has an important role in Fugard's work, because before writing these series of plays, he "was acutely conscious of how imitative and derivative his plays were and that he needed to find some authentically indigenous form or style" (Foley 150). The political and also personal events which happened in 1960 gave him the power to find and establish a particular dramatic style for himself. 
The simplicity of setting has been always evident in Fugard's plays. The play takes place in a room, almost an empty room, with only necessary props. "One door, one window (no curtains), two beds, a table and two chairs. Also in evidence is a cupboard of sorts with an oil-stove, a kettle and a few pots. The shack is tidy and swept, but this only enhances the poverty of its furnishings" (Fugard 2). Martin Orkin in his article "Body and State in Blood Knot/ The Blood Knot" mentions "[a]ll the scenes of the play are located within the home and within the family unit. We may see the play as partly concerned to explore the struggle of two young men within the safety of home and family, to find, within their bodies, identity" (20). The play is dealing with poverty, which is also neatly pictured in the setting of the place. "You should have been here this afternoon, Zack. The wind was blowing again. Coming this way it was, right across the lake. You should have smelt it, man. I'm telling you that water has gone bad. Really rotten! And what about the factories there on the other side? Hey? Lavatories all around us? They've left no room for a man to breathe in this world" (Fugard 10). The setting of the play also denotes the theme of poverty. All these cause a constant unity to be felt in the play.

Blood Knot circles around two main characters: Morrie and Zachariah Pietersen, two brothers, one light-skinned (enough to pass for white; "the South African expression for coloureds who looked as whites" (81) according to Kacer) and the other a black man, which brings to the reader's mind the possibility of different fathers, since they share one mother. But at the moment they seem to be parentless. Zachariah carrying a flat characteristic is completely illiterate and works as a gatekeeper at a park with footsore at his feet from standing all day at gate; he gives whatever he earns to his brother, the one with more complicated character. Morrie, Zachariah's half-brother, is the civilized, intellectual, educated, poetic, smart brother who stays at home and does the domestic chores in the house and plans for future with the money his brother earns. As it is apparent, the white brother acts as a white, having the control over his brother, being at home and just thinking about how to save money, which is an act of gaining power, and the black brother works out of the house in a dreadful situation, as it can be expected from a black man.

Contrary to Morrie who thinks of future, Zachariah lives in the present. Morrie is planning for a "small two-man farm" (Fugard9) somewhere out there in "the right place" (Fugard9) which is not absolutely Korsten with the money Zach earns. Complaining about restrictions Morrie's plans have caused, Zach stricks up a penpal relationship with a white girl Ethel Lange, "[a] corresponding pen-pal of the opposite sex" (Fugard14), although they are not aware of her whiteness from the beginning. Since Zach cannot read or write, Morrie write the letters for him which causes him to be aware of what happens between them. Although Morrie warned Zach of having relation with a white girl, "they don't like these games with their 
whiteness" (Fugard42), he insistently continues writing letters. After exchanging three letters, Ethel told him that she's coming to Korsten to meet him. Quarreling much on the subject, Morrie the white brother accepts to personify Zach. To prepare him for a date, Zach buys an "outfit, for a gentleman" (Fugard 50) with their saved money. Putting on his white clothes, their structural difference, the difference between the color of their skin became more apparent, despite their blood bond. Morrie begins to treat Zack like an inferior, calling him "swartgat" (Fugard 56) -"a farinaceous derogatory term for a black man" (Al-Qarni 1229)-, "horrible" and attacks Zachariah with his umbrella. Although Ethel's coming to Korsten is nullified, both of them are aware of the difference in their skin tone.

Blood Knot is a play about the union of opposites; the union of two different world of blacks and whites. Zach is the representative of the blacks and Morrie also the representative of the whites, but metaphorically. The tension which can be felt between the brothers in the play is the same as the tension among whites and blacks in a colonized country. Foley has also confirmed it by saying that the play is "on 'a symbolic level' or 'in suspended time' a representation of the black and white races in South Africa" (155). He also mentions that:

Morris may be interpreted as an image of the white colonist who has entered unbidden into the home of the black man in Africa, and has imposed his idea of order and control upon that environment. The play succeeds also in throwing up uneasy stereotypes of the "civilized", Apollonian white man and the "savage", Dionysian black, though without itself supporting such stereotypes. And the climax of the action presents a horrifying image of the pending racial apocalypse in South Africa if the white man continues to oppress and abuse his black "brother". (Foley 155)

Being considered as the agent of the whole black society and the white society, this can be deduced that the play is a microcosm of the real world. The characters in the play denote real human being living in the real society.

This union of the two brothers, or better to say, the union of blacks and whites is exactly what Homi Bhabha has talked about in The Location of Culture. According to Al-Qarni "Fugard is mainly preoccupied with portraying one of the most basic cultural and political theories of human consciousness and identity: it is the multiple dichotomous operating conflicting stances of colonizer/ colonized, white/ black, persecutor/ persecuted, oppressor/ oppressed, self/ other, and victim/ victimizer" (1226). On the other hand, Bhabha's theories deal with the relation of these binaries. He emphasizes the mutual relation between two parties, the 
colonizers and the colonized. What Bhabha called Hybridity and Mimicry which occur in the third space of enunciation can here be applied to the play.

\section{Bhabha's Theories and Fugard's Blood Knot}

Bhabha devoted the first chapter of his book to the idea of the third space of enunciation. In her article "A Postcolonial Reading of Pygmalion: A Play of 'Mimicry'" Sasani mentions that in the third space "no party has priority over the other" and the "power relationships are reciprocal and their identities are mutually constructed" (238).According to her, "[t]he equation of power is so complex in these relationships that the very assumption of the straightforward exertion of power is not plausible" (238). Sasani also declares that Homi Bhabha:

Emphasizes the mutual power relationship between the colonizer and the colonized. In his view, the power scheme is not a straightforward exertion of power from top to bottom, from the colonizer to the colonized. He deconstructs the binary opposition, the rigid distinction between the colonizer/the colonized, the black/white, and superior/inferior. In other words, he deconstructs Edwards Said's traditional notion of the way the colonizer straightforwardly treats the colonized as the Other, or the inferior. (Sasani 238)

In such a space none of the parties have priority over the other. A new culture and a new identity will engender by both the colonizer and the colonized. These changes lead to the reciprocal relationship between them.

There are different factors which contribute to shape this third space: the Mimicry strategy which is imposed on the colonized or the Other by the colonizer, the colonizer's desires and fears which he projects on the Other, the Hybridity which is unavoidable in such relations, and the intimidation of the colonizer in his relation with the colonized, to name a few. The mimicry strategy is defined as "the desire for a reformed, recognizable Other, as a subject of a difference that is almost the same, but not quite" (Bhabha122). Although it is used by the colonized as a strategy, it can be a threat for the colonizer. "Since becoming quite the same means that the colonizer's authentic identity is paradoxically imitable" (Sasani 238), he cannot accept the Other quite the same. It is considered as one of the factors, which makes the relation between two parties reciprocal, not straightforward from top to bottom. 
What comes out of all these exchanges between the colonizer and the colonized is the invention of a new theory what Bhabha calls the theory of Hybridity. This theory which challenges the colonizers established assumption of being at the center, demonstrates the transformed mimic man, which is the result of association with the colonizer. As one of the other factors effective in the birth of the third space, Hybridity is also considered as one of the important ideas proposed by Bhabha. Dehdari, Darabi and Sepehrmanesh in their article "A Study of the Notion of Bhabhasque's Hybridity in V.S. Naipaul's In a Free State" state that:

One further point of significance concerning the true nature of interaction between the colonizer and the colonized is that apparently, the colonized are the only victims of colonial system; however, there is a problem in front of the colonizer which makes them victim as well. This problem may be: fading identity... . This may be one of the reasons Paul Jay states that -all cultural forms are hybrid... . Fading identity can be a direct result of hybridity in culture. Fading identity may lead to identity crisis both in the colonizing and colonized cultures. The fact that hybridity 'threatens the authority which is based on categorizations of difference' is among the most dramatic aspects of Bhabhaesque hybridity. (137)

One of the outcomes of colonial mimicry strategy is the fading of identity. This also leads to emergence of a hybrid. Both of them are considered as problems a colonizer may face in a colonial relationship.

Considering Morris "as an image of the white colonist who has entered unbidden into the home of the black man in Africa" (Foley 155), Zach can be interpreted as the colonized or the other. Morris the light-skinned brother is in the role of the colonizer, and Zack the dark-skinned brother has the role of the colonized. In contrast to the bond between them, the blood knot, the illumination of the relation between them is much more complex. Certainly the relation is not Said's straightforward exertion of power from top to bottom, or from the colonizer to the colonized. According to Bhbaha each of these parties plays a significant role to keep maintenance in the relationships.

From the beginning of the play, the internalized inferiority is comprehensible in the personality of the black brother, Zach. Living under the Apartheid regime, his blackness and his inferiority to the whites were with him during his whole life. Being inferior has been imposed on him by the whole society, even his mother. $\mathrm{He}$ recalls some painful memories from his childhood when his brother was preferred by his mother even in their playing by giving the toys to Morris. In scene three, the brothers remember their mother singing lullaby for them in their childhood, even 
the lullabies recited for each brother is apparently different. The lullaby the mother sang for Zach was:

\section{ZACHARIAH. Do I! [He laughs and then sings:]}

'My skin is black

The soap is blue,

But the washing comes out white.

I took a man

On a Friday night;

Now I'm washing a baby too.

Just a little bit black,

And a little bit white,

He's a Capie through and through.' (Fugard 34)

But for Morrie, his mother sang: "Lullabye baby", "You'll get to the top." (Fugard 34). So, even from his childhood his inferiority has been internalized in him by reminding him all the time of his blackness. According to Ai-Qarni "the lull songs and the toys are used as cultural symbols of existence, such a stance discloses that racial discrimination saturates both the South African community and families" (1228). As the inferiority is imposed on Zach, the superiority is also internalized in Morris, too. This has been continued till present. In scene four, Morrie reminds his blackness to him. In this scene, according to Al-Qarni,"Morrie drives Zach to a direct verbal confession of his blackness and his actual position of being the 'Other'" (1229).

MORRIS. That's better. Go back to the beginning. Give me that first fact, again. [Pause.] It started with Ethel, remember Ethel ... is

ZACHARIAH. $\quad . .$. is white.

MORRIS. That's it. And ...

ZACHARIAH. $\quad$... and I am black.

MORRIS. Let's hear it. 
ZACHARIAH. Ethel is so ... so ... snow white.

MORRIS. And ... come on ...

ZACHARIAH. And I am too ... truly ... too black.

MORRIS. Now, this is the hard part, Zach. So let it hurt, man. It has to hurt a man to do him good. I know, just this one cry and then never again ... Come one, Zach ... let's hear it.

ZACHARIAH. I can never have her.

MORRIS. Never ever.

ZACHARIAH. She wouldn't want me anyway.

MORRIS. It's as simple as that.

ZACHARIAH. She's too white to want me anyway. (Fugard44)

As it is shown, the colonizer, despite the peaceful and reciprocal relationship between him and the colonized, tries to remind him of his superiority every now and then. When this inferiority has been internalized for the colonized, the colonizer can impose his desires and strategies on him. Accepting his inferiority, Zach accepts to work outside the house in that dreadful situation, while his brother is just at home and plans for future, since he is white. But gradually as the play goes on, Bhabha's theories and strategies demonstrate themselves.

Employing Bhabha's "colonial mimicry strategy" Morris wants to make Zach the same as himself "but not quite" of course (Bhabha 122). On the other hand Zach, aware of his inferiority and his difference, is eager to become like his brother. According to Bhabha, as David Huddart mentions in his book Homi K. Bhabha,"colonial discourse wants the colonized to be extremely like the colonizer, but by no means identical" (qtd. in Huddart 40). Thus, "the play between equivalence and excess makes the colonized both reassuringly similar and also terrifying" (Huddart 41). Zach, aware of his problems in using appropriate words, tries to learn using them. He tries to mimic his brother and to use the words as his brother uses them. In scene one, when Zach comes home, Morris asks him about the work. It is apparent in their talking that Zach as the inferior one needs Morrie's help in learning appropriate words. 
ZACHARIAH. He said: 'Go to the gate or go to hell.'

MORRIS. That's an insult.

ZACHARIAH. What's the other one?

MORRIS. Injury!

ZACHARIAH. No, no. The long one.

MORRIS. Inhumanity!

ZACHARIAH. That's it. That's what I think it is. My inhumanity from him. 'Go to the gate or go to hell.' What do they think I am? (Fugard 6)

The importance of language and having the ability to use it appropriately are emphasized in the first chapter of Fanon's Black Skin, White Masks (1967). According to him one of the factors which can make a Negro of Antilles "whiter" is his mastery of the French language. So, in order to have the power to live among the whites, the colonized people have to master the language. The importance of this phenomenon can be comprehended also when Fanon says: "[i]n France one says, 'He talks like a book'. In Martinique, 'He talks like a white man"' (Fanon 11).In this play too, Zach, the colonized, tries to master the language in order to free himself of the "inferiority complex" (Fanon 9) which is spread among the colonized in a colonial environment. Zach knows that as the Other he needs Morrie's help to improve his ability in using correct words. Later on, in scene three, they are again talking about the day, and there is another example of learning words:

ZACHARIAH. Ja. They call a man a boy. You got a word for that Morrie?

MORRIS. Long or short?

ZACHARIAH. Squashed, like it didn't fit the mouth.

MORRIS. I know the one you mean.

ZACHARIAH. $\quad J a$, then say it.

MORRIS. Prejudice.

ZACHARIAH. Pre-ja-dis. 
MORRIS. Injustice!

ZACHARIAH. That's all out of shape as well.

MORRIS. Inhumanity! (Fugard24)

On the other hand, to complete this mutual relation, Morris cares for Zach. He wants to protect him from the insults he faces in public. He becomes anxious and tries to find solutions. He is also eager to teach him new words. And he also teaches him small but important issues like how to choose foot salt. He reads poems for him. He knows it as his duty to prepare the washbasin of hot water and foot salt every night at the specified time for Zach to alleviate the pain he suffers from standing the whole day at the gate on his feet.

The alarm rings and Morris jumps purposefully to his feet. He knows exactly what he's going to do. First, he winds and resets the clock, then lights the oil stove and puts on a kettle of water. Next, he places an enamel wash basin on the floor in front of the other bed and lays out a towel. $\mathrm{He}$ feels the kettle on the stove and then goes to the door ... . he sees someone coming. A second burst of activity. He places a packet of foot salts beside the basin and finally replaces the kettle. Zachariah comes in through the door. (Fugard 3)

The stage direction explicitly shows the importance of the task for Morris. This is repeated every night before Zachariah comes home. To have Zach beside himself, he knows that he needs to maintain this mutual relationship. He also prepares the dinner, reads the Bible and does the house chores. Instead, he as a colonizer projects his desires onto the colonized. For more than one year, whenever Morris comes to his brother's house, he gets whatever Zach earns and saves to buy the farm. He is making "a reformed, recognizable Other" (Bhabha 122). He uses Zach as a tool to achieve what he wants, as Zach uses him to achieve what he wants. Here the mutual relation between the colonizer and the colonized, what Bhabha emphasizes, is totally performed.

Although this is the desire of both to become the same, both of them are also horrified to become exactly the same. So the reader is witnessing some resistance in both the colonizer and the colonized. Zach submits to Morris's desires, though he resists in some points to show his disaccord. Knowing Morris's plans for the future and its importance for him, he still complains about the situation and the restrictions Morris's presence has made, so he wants to go back to the time before his coming, when he and Minnie had lots of fun together. Minnie is one of his friends with whom he spends time every night before his brother (metaphor for the 
colonizer) comes to his house. As a means of resistance to become totally like Morris, he wants to go back to the past. In scene one, he is remembering Minnie and what happened between them:
ZACHARIAH.
Wait, man! I'm remembering it now. He used to come, I thought to myself, with his guitar to this room, to me, to his friend, old Zachariah, waiting for him here. Friday nights it was, when an $o u$ 's got pay in his pocket and there's no work tomorrow and Minnie's coming. Now there was a friend for man! He could laugh, could Minnie, and drink! he knew the spots, I'm telling you ... the places to be, the good times ... and -Ja! [Reverently.] Minnie had music. (Fugard8)

As another example of his resistance, one can refer to his use of indigenous words. Although Zachariah tries to imitate Morrie in talking like an educated man, he still uses indigenous words, such as $J a$ (yes), hot not (corrupt form of 'Hottentot'), doek (head-scarf), ou (common mode of address to man or boy), $A g$ (oh), voetsek (rough command to go), $A i$ (exclamation expressing pain), hamba (go), Ek se (exclamation 'hey') and so on. As the play goes on, the reader sees how much this resistance goes further till Zach, unresponsive to Morris's plan, starts a pen-pal relationship with a white girl and spends his earnings for his own goals, buying a suit appropriate for a gentleman, to make his brother ready to meet Ethel. According to Bhabha "The menace of mimicry is its double vision which in disclosing the ambivalence of colonial discourse also disrupts its authority" (126). This anxiety of having the same Other, leads to how Morris behaves at the end of the play.

MORRIS. $\quad$... Hey, swartgat!

ZACHARIAH [playing along]. Ja, Baas?

MORRIS. Who are you?

ZACHARIAH. Your boy, Zach, Baas.

MORRIS. And who am I?

ZACHARIAH. Baas Morrie, Baas. (Fugard64)

And later, although they are playing a game just as a joke, he even goes further and addresses him more savagely:

[Zachariah tries to escape, but Morris catches him with the crook of the umbrella.] 
MORRIS. Wait, wait! Not so fast, John. I want to have a good look at you. My God! What sort of mistake is this? A black man? All over, my boy?

ZACHARIAH. Sorry, Baas.

MORRIS. Your pits and privates?

ZACHARIAH. Ja, Baas.

MORRIS. Nothing white?

ZACHARIAH. Forgive me please, my Baas.

MORRIS. You're horrible.

ZACHARIAH. Sorry, Baas.

MORRIS. You stink.

ZACHARIAH. $\quad$ Please, my Baasie ...

MORRIS. What did you mean crawling around like that? Spoiling the view, spoiling my chances! What's your game, hey? Trying to be an embarrassment? Is that it? A two-legged, bloody embarrassment? Well, we'll see about that. I hate you, do you hear? Hate! ... Hate! ... Hate! ...

[He attacks Zachariah savagely with the umbrella. When his fury is spent he turns away and sits down.] (Fugard69-70)

As Huddart has mentioned in his book "colonial discourse at once demands both similarity and difference in the figures of the colonized..." (44). This similarity and difference is the cause of the anxiety which exists in the colonizer. The colonizer wants the colonized to use him for reaching to his own goals but at the same time he wants to remind him of the differences between them. Morris, as the colonizer wants Zach, the Other, for his own benefits. This complex relation between two parties shows their entrance to the third space. Both the colonizer and the colonized make a mutual relationship which is just possible in the third space.

In the third space, the relation between the colonizer and the colonized is not the top to bottom supposed relation. Both of them have benefits for each other. In this play too, the existent relation between two brothers is formed in the third space. All the examples mentioned above show the mutual and reciprocal relation of the colonizer and the colonized. Morris does not look at Zach as just the inferior Other, as was supposed in the theories of Edward Said. And also even Zachariah uses 
Morris for his own benefits. Zach does not look at him just as a master who must be obeyed because of the color of his skin. Both of them shape a new identity for each other. The colonizer's identity is shaped in this third space by the colonized and also the colonized identity is shaped by the colonizer.

Despite all these reciprocal relations, at the end of the play, Morris the colonizer, putting on his suit treat the Other as if to remind him of his superiority, power, and authority. Although he tries to hide it, his rage and hatred toward Zach are revealed in their play. This way he ascertains their structural difference despite the similarities he has formed. They are dependent on each other notwithstanding their opposition, and they are both aware of this, which causes them to stick together. As the stage directions testify, they are satisfied with this and go to bed to have the same usual day tomorrow.

[Zachariah Stands above Morris on the point of violence. The alarm clock rings. Morris crawls frantically away, then jumps up, rushes to the table and turns up the lamp. Zachariah goes to his bed and sits. A long silence. They avoid each other's eyes. Morris takes off the jacket. At the window.] (Fugard72)

The mutual relation between the colonizer and the colonized, the mimicry strategy the colonizer uses, the resistance strategy employed by the colonized, the colonizer's projection of desires and fears on the Other, and other methods and strategies used in the third space are self-explanatory of what Bhabha calls Hybridity. Bhabha defines hybridity as "the name of this displacement of value from symbol to sign that causes the dominant discourse to split along the axis of its power to be representative, authoritative" (Bhabha 162). Hybridity is also considered as an anxiety for the colonizer since it deconstructs the established assumption of the colonizers' uniqueness. So, as Mizutani argues, this concept of hybridity challenges the "logic of permanent presence, or of never-changing identity" (36) of colonial discourse. The hybrid is a new born identity. It can be born in the third space; a new identity which is formed in a new space.

He argues that hybridity is a new mixed identity for both the colonizer and the colonized. Dehdari states that "hybridity enables the establishment of communication between cultures. It is obvious that the two cultures cannot enter a proper interaction via the application of absolute domination on the side of one culture" (138). So a new culture is born, a culture which is a mixed culture of both parties of the colonizers and the colonized. It can be concluded that the concept of hybridity is very close to the concept of colonial mimicry. 
Fugard's play Blood Knot depicts what Bhabha believes and says about the discourse of postcolonialism in his book The Location of Culture. The new identities are shaped in the new space. Zach (Zachariah) and Morrie (Morris), although half-brother, are exemplifying the colonized and the colonizer respectively. Although at the beginning of the play the oppressed and the oppressor are not recognizable but as the play goes on it becomes clear. The relation between them follows what Bhabha proposes.

\section{Conclusion}

Authors such as Athol Fugard played an important role in reclaiming their society by their works of art. On the other hand, postcolonial theories help the readers to have a better understanding of different layers of meaning except the one apparent on the surface. According to Bhabha, in the third space of enunciation the relation between the whites and the blacks becomes reciprocal. Different factors, such as the mimicry strategy which is imposed on the colonized or the Other by the colonizer, the colonizer's desires and fears which he projects on the Other, the Hybridity which is unavoidable in such relations, and the intimidation of the colonizer in his relation with the colonized shape the third space. Bhabha believes that the new identity formed in the third space makes none of them the winner or the loser. This mutual relationship continues till both parties follow the rules of the third space. Since there is no way out of this colonial situation, both parties, aware of their duties try to maintain the relation which can be beneficial for both of them. It shows that both the colonizer and the colonized depend on each other and none of them can be considered as a separate and independent entity.

Zachariah plays the role of Black or the Other while Morris is the White or in other words, the colonizer. Both the blacks' inferiority and the whites' superiority have been internalized in them for a long time. Despite their difference in the color of their skin, they try to live peacefully in the third space. Although mimicry strategy is used by the colonized, at the same time they use some strategies to prevent total resemblance. Since the colonial mimicry is considered as an anxiety for the colonizers, they, at the same time, keep their distance by treating the Other like an inferior. They are dependent on each other notwithstanding their opposition, and are both aware of this, which causes them to stick together. It has been proven to both parties that to avoid conflicts and collisions, it would be better to live under the regulations of the third space. 


\section{References and notes:}

Al-Qarni, Shunayfaa Mohammed. "Manichean and Dichotomous Opposites in Athol Fugard's Blood Knot."Journal of Language Teaching and Research 6.6: 2015.122531. Pdf.

Ashcroft, Bill. "Caliban's VoiceWriting in the Third Space." Communicating in the Third Space. Ed. Karin Ikas, Gerhard Wagner. 2009. New York: Routledge. 107-22. Pdf.

Bhabha, Homi K. The Location of Culture.1994. London: Routledge. Print.

Cohen, Derek. "A South African Drama: Athol Fugard's 'The Blood Knot'." Modern Language Studies 7.1: 1977.74-81.Pdf.

Crow, Brian. "Athol Fugard."Postcolonial English Drama: Commonwealth Drama since 1960.Ed. Bruce King.1992. London: Mcmillan. 150-64. Pdf.

Dehdari, Ali, BitaDarabi,Mehdi Sepehrmanesh. "A Study of the Notion of Bhabhasque's Hybridity in V.S. Naipaul's In a Free State."International Journal of Humanities and Social Science 3.3: 2013.135-44. Pdf.

Fanon, Frantz. Black Skin, White Masks. 1986. London:Pluto Press. Pdf.

Foley, Andrew John. "Liberalism in South African English Literature 1948-1990: A Reassessment of the Work of Alan Paton and Athol Fugard."Natal University.Diss. 1996.Pdf.

Fugard, Athol. Blood Knot and Other Plays.1991. New York: Theatre Communications Group. Print.

Huddart, David. Homi K. Bhabha. 2006. London: Routledge. Pdf.

- - - . "Hybridity and Cultural Rights: Inventing Global Citizenship." Reconstructing

Hybridity: Post-Colonial Studies in Transition.Ed. Joel Kuortti and Jopi

Nyman.2007. New York: Rodopi. 21-41. Pdf.

Ikas, Karin, Gerhard Wagner. Introduction.Communicating in the Third Space. Ed. Karin Ikas, Gerhard Wagner. 2009. New York: Routledge. 1-7. Pdf.

Kacer, Tomas. "Criticism of Apartheid in Blood Knot in Comparison with Two Trains Running and Philadelphia, Here I Come!." Brno Studies in English 34.14: 2008.7988. Pdf.

Kapoor, Ilan. "Acting in a tight spot: HomiBhabha's postcolonial politics." New Political Science 25.4: 2003.561-77.Pdf.

Mahlauli, Mavis B., End Salani, Rosinah Mokotedi. "Understanding Apartheid in South Africa through the Racial Contract. "International Journal of Asian Social Science 5.4: 2015.203-19. Pdf.

Mirza Muhammad Zubair Baig., Celebrating or Mourning Patriarchal Love: The Case of Curious Courtships in Marquez's Love in the Time of Cholera.Khazar Journal of Humanities and Social Sciences.Khazar University Press.Baku, Azerbaijan.80-91

Mizutani, Satoshi. "Hybridity and History: A Critical Reflection on Homi K. Bhabha's Post-Historical Thoughts." Ab Imperio 4: 2013. 27-48. Pdf.

Mshengu, Robert K. "Political Theatre in South Africa and the Work of Athol Fugard. "Theatre Research International 7.3: 1982.160-79.Pdf.

Orkin, Martin. "Body and State in Blood Knot/ The Blood Knot." South African Theatre Journal 2.1: 1988.17-34.Pdf. 
Rukundwa, Lazare S, Andries G van Aarde. "The Formation of Postcolonial Theory." HTS 63.3: 2007.1171-94.Pdf.

Said, Edward.Orientalism.1978. London: Penguin Classics. Pdf.

Sasani, Samira. "A Postcolonial Reading of Athol Fugard's"Master Harold" ... and the Boys." Mediterranean Journal of Social Sciences 6.3: 2015.458-65.Pdf.

- - - . "A Postcolonial Reading of Pygmalion: A Play of 'Mimicry'." International Journal of Applied Linguistics \& English Literature 4.2: 2015.238-45.Pdf.

Wisker, Gina. Key Concepts in Postcolonial Literature.2007. Hampshire: Palgrave Macmillan.Print.

Yazdiha, Haj. "Conceptualizing Hybridity: Deconstructing Boundaries through the Hybrid."Formations 1.1: 2010.31-38. Pdf.

\title{
Summary
}

\section{Third Space, Hybridity, and Colonial Mimicry in Fugard's Blood Knot}

\author{
Parvin Ghasemi \\ Shiraz University, Iran
}

\author{
Samira Sasani \\ Shiraz University, Iran
}

\section{Fatereh Nemati}

Shiraz University, Iran

Literature, as a branch of Humanities, has a significant role in demonstrating the problems and the realities of a society. Therefore, the literary texts written in South Africa, had a major role in the victory of people against the policy of Apartheid, according to which the whites were segregated from non-whites. Harold Athol Lanigan Fugard is one of the writers, who showed his hatred and dissatisfaction to the world, with his plays. He is known for his deeply rooted and controversial anti-apartheid plays. His Blood Knot (1961) has been chosen in this study, in which the negative implications of colonialism and racism can be explored. Bhabha is one of the influential critics whose works give priority to the agency of colonized people. The relation between the colonizer and the colonized will be scrutinized subsequently according to what Bhabha mentioned in his influential book The Location of Culture.

Keywords: Post -colonialism, Homi Bhabha, Athol Fugard, Blood Knot, Third Space, Hybridity, Colonial Mimicry 